\title{
The Evaluation of Surrogacy's System in Indonesia as Comparison to India's Legislation
}

\author{
Mega Dewi Ambarwati \\ Airlangga University, Indonesia \\ megal0meggy@gmail.com \\ Ghina Azmita Kamila \\ Airlangga University, Indonesia \\ megal0meggy@gmail.com
}

\begin{abstract}
In today's age, marriage life is can be complicated with problems like infertility. In the face of this problem, couples have used surrogacy as a potential fix. Surrogacy poses a unique problem in Indonesia, because such a concept remains culturally taboo and no legal system exists to regulate the process and the responsibilities of the surrogate mother. Thus, other countries that have created a legal infrastructure for surrogacy offer valuable paradigms and best practices. This study seeks to compare surrogacy law between Indonesia and India, with the overall goal of suggesting policies to better regulate surrogacy within the former country. This study uses comparative legal research methodology through the functional method because Indonesia and India face the same social problem of surrogacy. The result reveals that it needs a legal system on surrogacy and surrogate mother as the legal certainty for any individual especially spouse who could not have offspring along with some reasons such as minimalize prostitution and unregistered marriage, prevent dispute, and to develop scientific field. The study concludes that Indonesia requires stronger legal infrastructure for surrogacy that will not only provide legal certainty for surrogate mothers and families using surrogacy but will also minimize prostitution and unregistered marriages, mitigate domestic disputes, and catalyze scientific innovation.
\end{abstract}

KEYWORDS: Surrogate Mother, Surrogacy, Indonesia, India.

Copyright $\odot 2019$ by Author(s)

This work is licensed under a Creative Commons Attribution-ShareAlike 4.0 International License. All writings published in this journal are personal views of the authors and do not represent the views of this journal and the author's affiliated institutions.

\section{HOW TO CITE:}

Ambarwati, Mega Dewi \& Ghina Azmita Kamila. "The Evaluation of Surrogacy's System in Indonesia as Comparison to India's Legislation” (2019) 6:2 Lentera Hukum 253-266.

Submitted: May 19, 2019 Revised: May 20, 2019 Accepted: May 20, 2019 


\section{INTRODUCTION}

Within Indonesia, marriage offers families the right to have offspring. However, this right is not assured because of problems of infertility. One common solution to overcome this problem are artificial methods of fertilization. One in particular is surrogacy, where conception can be done in the womb of another woman called a surrogate mother. Indonesia has yet to have legal certainty on both the process of surrogacy and the surrogate mother. However an existing regulation may provide indirect provisions: the law on health; regulation of ministry of health Number 039.Menkes/SKS/2010 on the Implementation of Assisted Reproduction Technology Services; Government Regulation No. 61/2014 on Reproductive Health; Fatwa of the Indonesian Ulama Council (MUI) on May 26, 2006. The law prohibits surrogacy, impeding existing interest and efforts to facilitate surrogacy. Tata Taofikurrahman, a judge in religious court in Bandung, adds his own commentary that it necessary to make guidelines so that there are procedures regulating the surrogacy process. He also adds that surrogacy and surrogate mothers must have a legal marriage; if not, surrogacy is forbidden.

In contrast, India became the first country in 2002 to legalize surrogacy. For the past 10 years, there are more than 3000 children born through surrogacy process in India. Surrogacy in India is protected by the Assisted Reproductive Technology Regulation Bill 2010. These provisions state that: "The surrogacy process can be carried out by single parents or married couples, the process of Intended Parents must pay all costs used during pregnancy until the birth of the baby, Surrogate Mother is permitted to receive compensation, but does not mention a specific number, the name listed in the child's birth certificate is the name of Intended Parents and therefore automatically considered as legitimate parents of the child."

With the advent of in Vitro Fertilization (IVF) in 1970, couples unable to conceive had a greater chance of having children. This technology, in turn, boosted the concept of surrogacy. In the United States, surrogacy was formally described a woman who is willing to be hired by her womb, with an agreement to conceive, give birth, and surrender her baby in return for some material ${ }^{2}$.Though surrogacy is quite promising for handling several cases of infertility, this process is inhibited by prevailing Indonesian laws and ethical considerations. Because surrogacy is considered "unnatural," it is not protected under Indonesian Law. Indonesian law implicitly prohibits the practice in Article 127 of Health Act Law Number 36 of 2009 which stipulates that "unnatural" pregnancy efforts can only be carried out by a lawful couple with the following provisions: (a) the result of both sperm and ovum fertilization from the concerned couple should be implanted in the womb of the wife from which the ovum originates; (b) carried out by health workers who have the expertise and authority for it; and (c) it should be done in certain health care. Because of how

Hunter-Henin, M. (2008).Surrogacy: Is there Room for a New Library between the French Prohibitive Position and the English Ambivalence. England: Oxford University Press.

2 Spivack, C. (2010). The Law of the Surrogate Motherhood in the United State.58 AJCL.Oklahoma City University School of Law. 
uncompromising these existing provisions are, Indonesia crucially needs a legal system that is more compatible with the growing demand for surrogacy. Surrogacy in India offers a promising example, as it answers the needs of its citizens for the problem of infertility. is necessary to establish a legal regulation on surrogate mothers as a form of legal certainty so that the law in Indonesia can develop according to the evolving needs of Indonesian society.

\section{EXISTING LEGAL PROVISIONS OF SURROGATE MOTHER AND SURROGACY IN INDONESIA}

In return for the "service", the surrogate mother receives rewards which has been agreed prior the surrogacy agreement, and a surrogate mother is required to sign an agreement to immediately hand over the baby into the family that has been hired. As its development there have been two types of surrogacy. First, gestational surrogacy: the embryo taken from a husband's sperm with the ovum from the wife will be met through IVF (In Vitro fertilization) technology, and then it will be implanted in the womb of a surrogate mother. Second, genetic surrogacy: The ovum cell that participates in forming an embryo is the surrogate mother's cells while sperm is taken from the husband. Even though the surrogate mother also participates in being the owner of the ovum, she still has to surrender the child she conceived and gave the baby to the husband and wife who performed the surrogacy procedure.

The practice of transferring embryos into other uterus was illegally reported by the Indonesian Ulama Council (MUI) on 26 May 2006, "All jurists do not allow the womb to be rented in various forms." Jurists and health experts have issued a fatwa that allows couples to use technology with fertilization, however have specified that no third party, like a surrogate, can be involved. Article 1338 of the Civil Code states related to the principle of freedom of contract, where the parties who are bound in the contract are free to make and determine the contents of the agreement. Article 1338 of the Civil Code mentioned that "All agreements made legally apply to the laws for those who make them." However, the existing principle of freedom of contract must not violate the legal requirements of the agreement in Article 1320 of the Civil Code: (a) agreements of all parties; (b) competence of all parties; (c) concern with the certain things; and (d) lawful. Here, lawful is one of the validity agreements that should be well considered, in which does not be in conflict with the laws, regulations, morality, and public order (Amelen, 1991).

The rights of baby born by surrogate mothers in Indonesian law are related to Article 27 of Law Number 35 of 2014 on Amendments to Law Number 23 of 2002 on Child Protection Article 27 on "Identity Rights": (a) each child's identity must be given from birth; (b) the identity as referred to paragraph (l) is set forth in the birth certificate; (c) the making of birth certificates is based on a statement from the person who witnessed and/or assisted the birth process; (d) a child whose birth process is unknown and whose parent is unknown, the birth certificate for the child is based on 
the information of the person who found it and is equipped with the police investigation report.

In Article 127 of Law Number 36 of 2009 on Health has stipulated that pregnancy efforts outside the natural way only be carried out by a legal married couple with the following provisions: (a) the results of the conception of sperm and ovum from the concerned husband and wife are implanted in the womb of the wife from which the ovum originates; (b) carried out by health personnel who have the expertise and authority for the procedure; and (c) on the facilities of certain health services. The method or effort of pregnancy outside the natural way other than those provisions, including surrogate mothers, legally cannot be obtained in Indonesia. Therefore, there is no legal protection for the parties in the surrogacy agreement or leasing a womb related to surrogate mother.

\section{THE IMPLEMENTATION OF SURROGACY IN INDIA}

The procedure of surrogacy practice must be carried out with purpose and reasonable criteria. Paragraph 4 (ii) of Indian bill stipulated the following qualify for a reasonable purpose: (a) one or both spouse suffer infertility which officially has been proven by a doctor's statement; (b) merely for the altruistic surrogacy; (c) not for commercial purposes; (d) not in purpose to sale the baby, use for prostitution or other forms of exploitation; and (e) any other conditions or diseases that may be determined by regulations made by the representative board. Paragraph 4 (iii) of Indian bill stipulates: a feasibility license for spouse who are intending to do surrogacy is issued by the appropriate authority and should fulfill the following conditions: (a) the age of the spouse is between 23 to 50 years for a woman and 26 to 55 years for man; (b) the spouse have been married for at least five years and are citizens of India; (c) spouse who intend to no longer have a living child (biologically or adopted or substitute), with the exception of children who experience mental, physical or threatening mental disorders, and have been certified by the District Medical Council; and (d) for other conditions will be determined in the regulations.

Paragraph 48 (a) of the Bill: The National Prize Collection Agency with the prior approval from the central government can make regulations to provide fulfilment of other conditions where a certificate of eligibility for a spouse who intends to do surrogacy, can be issued by the appropriate authority. Clause 4 of the Bill states that a surrogacy procedure and the eligibility requirements must be fulfilled by the couple who intend to perform surrogacy ${ }^{3}$. The bill was also made to determine health conditions or other diseases suffered by a spouse as a basis for conducting surrogacy procedures.

The law delineates a variety of other requirements. Paragraphs 4 (iii) (b) (II) of the Bill: no one but a close relative of a spouse who will do surrogacy and act as a

Kala, M and Rao, N. PRS Legislative Research "Issues for Consideration: The Surrogacy (regulation) Bill. p 1. Available from www.prsindia.org/.../Surrogacy/Issues\%20for\%20 Considerat...PDF accessed on November $22^{\text {nd }}, 2016$ 
surrogate mother and be permitted to undergo surrogacy procedures in accordance with the provisions of this Law. The bill also stipulates that surrogate mothers and couples who will conduct surrogacy are required to obtain a feasibility and essentiality certificate from the relevant government authority at the central or state prior the process. However, the bill does not specify the period of time the relevant government authority will provide this certificate ${ }^{4}$.

The bill requires various conditions for prospective surrogate mothers. After fulfilling these conditions, a surrogate mother can obtain a certificate of eligibility from the authority appointed by the government. Interestingly, one condition is that she is a 'close relative' of the couple who will carry out the surrogacy process.

Table 1. India Surrogacy Bill 2016

\begin{tabular}{|l|l|}
\hline \multicolumn{2}{|c|}{ INDIA SURROGACY BILL 2016 } \\
\hline $\begin{array}{l}\text { Type of surrogacy allowed (altruistic or } \\
\text { commercial) }\end{array}$ & $\begin{array}{l}\text { Altruistic (commercial } \\
\text { surrogacy prohibited) }\end{array}$ \\
\hline Payment to the surrogate & $\begin{array}{l}\text { Medical expenses and } \\
\text { insurance coverage }\end{array}$ \\
\hline Eligibility Criteria for commissioning parent(s) \\
\hline Requirement of being married & Yes \\
\hline Citizenship and/or residency & Citizenship \\
\hline Existence of a medical reason & $\begin{array}{l}\text { Must prove infertility i.e } \\
\text { inability to conceive }\end{array}$ \\
\hline Age & 25-35 years \\
\hline Relation to commissioning parent(s) & Close relative \\
\hline Requirement of being married & Yes \\
\hline Number of own children & At least one \\
\hline Number of times one can be a surrogate & Once \\
\hline Consent of the partner & No provision \\
\hline Legal guardian of the surrogate child & Intending couple \\
\hline $\begin{array}{l}\text { Imprisonment for engaging in commercial } \\
\text { surrogacy }\end{array}$ & Minimum l0 years \\
\hline
\end{tabular}

\section{LEGAL POSITION OF SURROGACY AGREEMENT IN INDIA}

The surrogacy agreement that has been applied in India. The provision outlines: (a) voluntary Surrogacy, depicted as surrogacy which is obtained voluntary; (b) paid Surrogacy, depicted as commercial agreement between commissioning and the women who obtain as surrogate mother; (c) altruistic Surrogacy, occurs in which the surrogate mother do not accept commission. The Indian Council of Medical Research (ICMR) in 2005 has established "national guidelines" for regulating surrogacy, but this is remains

4 Ibid. 
merely as a guideline. The Guidelines are limited within scope of ART, and the surrogate mothers must sign a "contract" with a childless spouse. There is no provision if the "contract" is violated against the rights of a born child in later.

\section{A. Legal Cases}

The Indian Supreme Court issued an official review on its agreement of surrogacy act in the case of Manji Yamada vs Union of India (2018) 13 SCC 518. Manji Yamada is a child from a Japanese couple who found obstacles on handing a legal letter for a baby born in Gujarat, India. The Indian Supreme Court legally gave ownership to the surrogate grandmother. In another case, Jan Balaz vs Anand Kota 2010 GUJ 21, a German citizen signed a contract with a surrogate mother and two children were born. The question of citizenship emerged because the child was born in India to an Indian surrogate mother but the father was German. . Gujarat High Court, bearing in mind the Supreme Court's findings on the baby Manji case, stated the case was primarily related to the relationship of a child with a surrogate mother, and with the donor mother.

This is an uncommon case because the applicant (biological parents of two babies) was a German citizen, but the surrogate mother was an Indian citizen. The applicant and his wife worked in England and lived there. The applicant and his wife have signed a surrogacy agreement with a surrogate mother. Furthermore, the surrogate mother agreed that she will have no responsibility for raising the child. Both biological parents would have a legal obligation to accept the child given by the surrogate mother and the child will have all inheritance rights from biological parents based on applicable law. However when the surrogate mother gave birth to two baby boys, their passports were made in India. The name of the applicant was displayed as father and the name of the surrogate mother was displayed as the mother.. The father said that Germany would never recognize the babies as a citizen, so the father submitted a petition letter stating that the refusal of passports to children violated Article 21 (the right to life) of the Indian Constitution. The High Court stated that this case was primarily related to child relations with gestational surrogate mothers and with donors of the ovum.

As showcased here, the absence of provisions results in biased decisions from the Court that are more likely to recognize surrogates as the formal mother. The Indian Supreme Court concluded that the wife of a biological father, who does not donate ovum, cannot be treated as a legitimate mother. The Gujarat High Court stated that, by providing ovum, a woman would not become a natural mother, because life does not occur in her womb, nor does she receive sperm for conception. Within the current legal framework, Indian Supreme Court stated that the court had no choice except to state that any baby whose born in India from Indian women are citizens of their country and therefore are entitled to receive passports.

It is clear that in the Jaz Balaz case, the contract proved to be insufficient in demarcating the rights of the parties and also resulted in issues such as citizenship and identity which were very important for children but did not have a place in the surrogacy agreement. In both cases above (Manji and Jan Balaz), Indian courts have 
taken a very pre-contractual position, perhaps as a way of encouraging commercial surrogacy, which contributed millions of dollars to the Indian economy ${ }^{5}$. What actually defines a surrogacy agreement breach is not provided anywhere in the Indian Contract Act, making it easier for certain parties to avoid accountability, which will make an innocent child unprotected and vulnerable.

This also introduces human rights problem because of the potentially harmful living conditions of surrogate mothers. Problems such as whether the parent country of the commissioning partner recognizes and accepts the nationality of the surrogate child are very important because the Indian Citizenship Law does not give citizenship to a child born to a surrogate mother and such things can leave a stateless child where citizenship is denied from both countries. For example, both Japan and Germany do not recognize surrogacy and therefore will not give citizenship to children born in India. ${ }^{6}$.cases offer valuable lessons in formulating surrogacy and surrogate mother rules in Indonesia.

\section{B. Legal Instrument of Surrogacy in India}

There are series of legal instruments of surrogacy law in India: Indian Council of Medical Research (ICMR) Guidelines on 2005 which were later considered as Assisted Reproductive Technologies (Regulations) of the 2008 Bill throughout the required revision of design modifications of Assisted Reproductive Technologies (Regulation) 2010 Bill and later Assisted Reproductive Technologies (Regulations) 2013 Draft Bill. The 2005 Guidelines stipulate that surrogate mothers cannot be genetically related to children. The mother must clearly understand that she would not have any rights to the child. All the rights and obligations concern with the intended parent and child that have been formulated in the surrogacy agreement will be considered protected: including in heritance and all other privileges that a child is born naturally with.

The Indian Law Commission revealed a report on August 2009 describing the following: (a) if a child is born as a consequence, of surrogacy with a foreign born biological father or mother, even if born in India, will not become an Indian citizen; (b) substitute mothers can receive compensation for carrying children including health care and medical expenses during pregnancy in section 34 (3); (c) Surrogate mothers will release all parental rights of the child once the amount is transferred; (d) prescribed age limit for surrogate mothers is between 21 and 35 years and no woman can act as a surrogate mother for more than five successful live births in her life, including her own children; (f) Individuals looking for surrogate mothers must sign a surrogacy agreement with the surrogate mother, which will be legally enforceable; and (g) if a foreign party fails to claim the birth through the assigned surrogate mother, the local office will be legally required to take the birth of a child and be free to surrender the child to the adoption agency.

\footnotetext{
5 Pande, A. (2014). Wombs in Labor Transnational Commercial Surrogacy in India.New York: Columbia University Press.

6 Ibid.
} 
The Constitution will regulate assisted reproductive technology and a National Advisory Council will be formed, which will determine: (a) completing the procedure for surrogacy clinical registration and complaints; (b) clinics for assisted reproductive technology; and (c) the rights and obligations of patients, donors, substitutes and children of violations as well as the punishments.

The 2016 Bill has been introduced into the Indian Parliament, which proposed to completely eliminate commercial surrogacy. The bill approved by the cabinet has not been ratified. The 2016 bill defines commercial surrogacy as "surrogacy or related procedures carried out for profits or prize money (in the form of cash or the like) beyond basic medical costs and insurance coverage" and is intended to crack down on uterine leasing business which potentially encourages exploitation. The bill intends to only allow altruistic surrogacy, where the surrogate mother is a close relative of the parent who will do surrogacy. The couple must also prove their infertility. Under the bill, all surrogacy clinics must be registered, surrogate mothers cannot be paid directly and there will be a National and State Council of Substitutes who will become regulatory authorities for the practice. Commercial surrogacy, leaving substitute children, exploiting surrogate mothers and selling /importing human embryos are listed as violations that can be punished by law.

In addition, all registered clinics must keep surrogacy record for 25 years. One provision in the Bill 2016 (also in the 2010 ART Bill) is the prohibition of single parents, homosexuals and spouses of parents who performed surrogacy. The Bill 2016 also prohibits women who do not have children or unmarried women as surrogate mothers. While ART 2010 bill recognizes commercial surrogacy and is provided for its regulation, the 2016 Draft Law considers extensive exploitation which is a product of commercial surrogacy. Highlights of the Draft Surrogacy (Regulation) are as follows: (a) surrogacy is an arrangement where the couple will accept surrogate mothers to bring their children; (b) the spouse is an Indian citizen and married for at least five years where one or both of them is infertile. Substitute mothers must be close relatives who are married and have their own children; (c) there are no other fees but medical expenses are made for surrogate mothers. Substitute children will be considered as biological children of married couples; (d) national and state governments will receive certificates for future partners and surrogate mothers. The authorities will also arrange a surrogacy clinic; and (e) carry out surrogacy for a fee, advertising it or exploiting a surrogate mother will be finished with a prison sentence of 10 years and a fine of up to 5 million USD.

The $102^{\text {nd }}$ Parliament Committee Report, the 2016 Draft Bill made a number of recommendations for the Bill on Relation (Regulation). The recommendations are as follows. First, altruistic commercial surrogacy should be done with no any compensation for surrogate mothers except medical and insurance costs related to pregnancy. The Parliamentary Committee recommends a surrogacy model based on compensation rather than altruistic surrogacy. Such compensation must pay attention to a number of things (including wages lost during pregnancy, counselling, psychological, and postpartum care). It is also noted by the Parliamentary Committee 
that the economic opportunities available for replacement through surrogacy services do not have to be completely dismissed. Under altruistic surrogacy, it is possible for women to provide reproductive employment for free without being paid unfairly and arbitrarily. Second, the implication of a substitute is "close relatives", surrogate mothers can only be close relatives of married couple. The Parliamentary Committee notes that altruistic seclusion by close relatives will always be out of force and not because of altruism. Third, the Committee recommends that the criteria of being a close relative must be removed to enable related and unrelated women to become surrogate mothers. This recommendation must clearly state that the surrogate mother will not donate her own ovum.

Fourth, surrogacy services is limited for Indian people who are legally married. The Committee then notes that there will be another part of society that might want a surrogate child, hence, the Committee recommends the eligibility criteria be widened and includes couples living at home, divorced women and widows. In addition, this facility must be extended to Indian Non-Residents, Indians, and Indian Foreign Citizens but not foreign nationals. Fifth, spouse intends to make surrogacy arrangements after an inability to become pregnant after 5 years due to unprotected coitus or other medical conditions prevent conception. The Committee recommends that the definition of "infertility" in the bill must be in accordance with the definition of the World Health Organization, where the inability to become pregnant after at least one year of unprotected coitus. Sixth, gamete donor (sperm and ovum). The couple who intend can only do replacement tests by proving infertility. Therefore, gametes from a partner can be made possible not because of infertility. In such cases, gametes will be asked to be donated by others. The Committee noted that there was no provision of Gamete donor in the bill. This recommends that provisions for gamet donations must be included in the bill. Seventh, abortion. The approval from the appropriate authority (appointed by the central or state government) is needed to carry out an abortion during surrogacy. The Committee recommends reviewing these requirements in light of the 1971 Medical Termination of Pregnancy Act which regulates abortion. He noted that time is very important in medical emergencies during pregnancy. In such cases, there may not be enough time to ask permission from the authorities to have an abortion to save the life of a surrogate mother. The Parliament Committee report is likely to lead to the current debate, in the Parliament Building.

Based on the 2016 Bill above, Indonesia can adopt several existing provisions, adapted to the needs of today's Indonesian society, by not violating the 1945 Constitution, morality, religion and customary law. A specific, clear, and complete law can be formulated as a guideline and foundation for couples interested in surrogacy in Indonesia. 


\section{A CASE FOR SURROGACY IN INDONESIA}

Surrogacy has been legalized in some countries such as USA, Brazil, and India. In India, where commercial surrogacy has been popular since 1992, surrogacy is not yet directly mentioned in law. However, only Indian citizens aged 21-35 years can become surrogates $^{7}$. A survey on 2006 shows that there are 231 surrogate mother in India. Based on the facts as well as the explanation about surrogate mother's law regulation in India, the following must be considered in Indonesia.

\section{A. Surrogacy Legalization is Better than Unregisterred Marriage}

The Legalization of Surrogacy in Indonesia is better than unregistered marriage cases in Indonesia. In some cases, infertility has made a husband deny his wife, and result in a husband choosing to divorce, get married with another women, or consider a second marriage as a solution under unregistered marriage. However, second marriage as well as unregistered marriage may become a misfortune for the first wife and permits the man to be polygamous ${ }^{8}$. Hence, if surrogacy is allowed by the legal system, a decrease in the number of divorces can be expected along with better living conditions for infertile wives.

\section{B. Surrogacy legalization will ensure surrogacy policy to prevent dispute}

As it has known before that, several cases of surrogacy in Indonesia happened in secret, even between the member of its familiy or close relatives. Thus, because surrogacy practices are not under control of a legal system, dangerous circumstances may arise. Formal regulation and policy can minimize potentially exploitive situations. : The following considerations can create a safer environment:

a. Surrogacy arrangements will always be regulated in contracts agreement between the parties

b. Surrogacy arrangements must provide financial support for substitute children when the death of the commissioning partner or individual before childbirth, or divorce between the intended parent if no one receives child delivery

c. Surrogacy contracts must always take care of life insurance for surrogate mothers

d. One of the intended parents must establish a relationship with prospective children in the womb of a surrogate mother because the bond of love and affection with a child primarily comes from biological relationships

e. Legislation itself must recognize a substitute child to be a legitimate child of a parent who becomes commissioning without the necessity for adoption or even the guardian's statement. 
f. Birth certificate from a substitute child must contain the name of the parent who performed the surrogacy procedure.

g. The right to private donors and surrogate mothers must be protected

h. Selective surrogacy, sex must be prohibited

i. The party allowed to become a surrogate mother has a kinship relationship with a married couple who performs surrogacy procedures.

\section{Surrogacy Legalization From Bioethics Perspective}

Medical development has found the new method namely artificial insemination or known as in vitro fertilization. This method is found in 1970s which develop to solve the problem of infertile spouse who wanted to have offspring. In line with the insemination by in vitro fertilization (IVF), the idea of surrogate mother has arose.

Since the development of In Vitro Fertilization (IVF), it has become possible to disentangle sexual intercourse, genetic parenthood and pregnancy, thus opening up the idea of surrogate mother ${ }^{9}$. Surrogacy does not obtained by the natural insemination which is not involving the sexual intercourse between the father and surrogate mother. The process of surrogacy is conducted with the biological technical development and obtained in the outside the uterus. Afterward, when the insemination happened, the embryo is put in the uterus of surrogate mother so therefore it can grow more perfectly in the uterus. In this case, the surrogate mother is merely has role as mediator and not as biological mother. The baby born is purely the biological children of the parents who rent the uterus and the DNA of surrogate mother will not include into the baby.

From the perspective of technology and economy, surrogate mother has promised to solve several cases of infertality. However, this process is constrained due to some obstacles as like the legal system, ethics consideration, and norms in Indonesia. In relation with bioethics, actually, bioethics has its own role to bridging knowledge and humanity, particularly, in the medical field. Based on bioethics principal, the relation between technology and medical cannot be forced to be implemented if the relation has negative influences. Moreover, the fact said that technological development is opposed with the culture. In this case, the way people thought compared with the expert's thought is quite different. It will cause gap between society and expert, and lead the society to follow with the technological development. In this point, bioethics has role along with the law as "the Guardian" for humanity side.

Surrogate mother from the perspective and bioethics principal as stated by Beauchamp and Childress can be seen in the following explanation. First, principle of respect to autonomy. Human being has freedom existence in choosing decision based on gut feeling, consciously and in respect to other human being. In surrogate mother case, medical personnel should be respect the eagerness of spouse to have offspring through the development of technology, however, in other side, the medical personnel have to appreciate and respect the surrogate mother as well as the baby so that it will

9 Cavaliere, G \& Savio L.D. (2016). The Problem with Commercial Surrogacy; A Reflection on Reproduction, Markets and Labour. Bio Law Journal, 2 at 73-91. 
create balance on the both side, as well. Afterward, the autonomy right of human being also will be fulfilled. Second, principle of justice. Every human being should not be compared with others, whether the gender, race, nation, religion, social status and so forth. Therefore, the existence of human being should be appreciated and they are having the same rights and chances to be treated with full of responsibility and honesty by the decision maker. However, the existence provisions should not be prohibited. Third, principle of beneficence. Every action taken should be performed truly as well as the beneficence of the actions, thus it will minimalize disadvantageous that will bear by the patients. But, the beneficence should be considered that it will not merely concern with economic or technological side without taking care of humanity side. Fourth, principle of non-maleficence. The actions toward the decisions should not make loss or increase loss. Although, surrogacy practice seems to advantage the biological parents, but the decision should be give advantageous to the both side. The decision must be involving the whole aspects and factors.

All in all, from the perspective of bioethics, all of the problems dealing with surrogate mother can be solved as long as the rights of human being are fulfilled. It can be in form by tolerance the differences, respect the decision they have made without loss anyone. But, the most important thing is, the decision should not prohibit the provisions or legal system. Since, one of law function, as mentioned above, along with ethics, is as The Guardians that will look after the human being as the truth human being, not as the object of technological development ${ }^{10}$.

\section{CONCLUSION}

The practice of surrogacy as well as surrogate mother has been occured in some countries, in which the practice has been legal in legal aspect. Indonesia itself has not been yet legalized the practice of surrogacy due to several obstacles. As a comparison, India is one of a country that has been legalized surrogacy since a long time ago. From the several law perspectives applied by India, hence Indonesia should use the legal aspect as refereces to legalize surrogacy. Seeing from some perspectives, surrogacy can provide good impacts such as minimalize prostitution and unregisterred marriage, prevent dispute, as well as scientic development as long as human not as the technology development.

\section{REFERENCES}

Amelen, F. (1991). Kapita Selekta Hukum Kesehatan Cetakan 1. Jakarta: GrafikaTamajaya.

Anand, P. Chambers of Ms Pinky Anand, Thomson Reuters Practical Law, https://uk.practical

10 Ratman, H. D. (2012). Surrogate Mother dalam PerspektifEtikadanHukum: BolehkahSewa Rahim di Indonesia? Jakarta: Kompas Gramedia. 
law.thomsonreuters.com/65815985?transitionType=Default\&contextData=(sc.Def ault)\&efirst Page=true\& $\&$ bhcp $=1$

Cavaliere, G \& Savio L.D. (2016). The problem with commercial surrogacy; A Reflection on Reproduction, Markets and Labour. Bio Law Journal, 2, p. 73-91.

Child Protection Law No. 23 year 2002

"Sewa Rahim di Indonesia dilakukan diam-diam". (Detik Health). https:/health.detik.com/ibu-dan-anak/1370505/sewa-rahim-di-indonesiadilakukan-diam-diam accessed on Saturday 05 Jun 2010.

Health Act Law No. 36 year 2009

Hunter-Henin, M. (2008). Surrogacy: Is there Room for a New Library between the French Prohibitive Position and the English Ambivalence. England: Oxford University Press.

Judiasih, S.D., \& Dajaan, S. (2017). Aspek Hukum Surrogate Mother dalam Perspektif Hukum Indonesia. JBMH.

Kala, M \& Rao, N. PRS Legislative Research "Issues for Consideration: The Surrogacy (regulation) Bill. p 1 www.prsindia.org/.../Surrogacy/Issues\%20for\%20 Considerat...PDF accessed on November $22^{\text {nd }}, 2016$

Lasker, S. P. (2016). Surrogacy. Ensyclopedia of Global Biioethics, 1-8.

Law and Policy on Surrogacy. "A Socio Legal Study in India 2015". Chapter III, http://shodhganga.inflibnet.ac.in/bitstream/10603/102125/11/11_\%20chapter\%203.pdf

Pande, A. Wombs in Labor Transnational Commercial Surrogacy in India. (New York: Columbia University Press. 2014)

Qaradhawi, Y. Status Hukum Anak Hasil Sewa Rahim. Fatwa-Fatwa Kontemporer Jilid, p. 660

Rachmadsyah, S. Surrogate Mother (Ibu Pengganti) on hukumonlinedotcom. http://www.hukum online.com/klinik/detail/lt4c562a3b4bba4/surrogatemother-(ibu-pengganti) accessed on August $9^{\text {th }}, 2010$.

Ratman, H. D. (2012). Surrogate Mother dalam Perspektif Etika dan Hukum: Bolehkah Sewa Rahim di Indonesia?. Jakarta: Kompas Gramedia.

Spivack, C. (2010). The Law of the Surrogate Motherhood in the United State.(2010). 58 AJCL.Oklahoma City University School of Law.

Svitnev, K. (2006). Legal control of surrogacy - International perspectives. http://www.jurconsult.ru/publications/ethical dillemas/13 Legal\%20control\%20 of $\% 20$ surrogacy $\% 20 \% 20$ international\%20perspectives.pdf. Accessed $21 \mathrm{Mar}$ 2019.

WHO (World Health Organization). (2010). Mother or nothing: The agony of infertility. WHO Bulletin, 88(12), 881-882. 
266 | The Evaluation of Surrogacy's System in Indonesia as Comparison to India's Legislation

This page is intentionally left blank 